\title{
The Analysis of MHPP Acceptability in Supporting National Energy Security
}

\section{SUYONO THAMRIN ${ }^{1}$, RITA AMBARWATI ${ }^{2 *}$, KHALIDA FASYA ${ }^{3}$}

\author{
1,3Universitas Pertahanan, Indonesia \\ 2Universitas Muhammadiyah Sidoarjo, Indonesia \\ Email: ritaambarwati@umsida.ac.id
}

Received 1 September 2020| Revised 14 September 2020| Accepted 2 Oktober 2020

\begin{abstract}
ABSTRAK
Respon penerimaan masyarakat dengan komitmen dan kemandirian menjadi kunci keberhasilan pembangunan infrastruktur energi terbarukan. Penelitian ini menganalisis akseptabilitas pembangunan PLTMH di Jawa Barat, sistem manajemen dan strategi pembinaan IBEKA sebagai LSM, dan rumusan strategi peningkatan akseptabilitas PLTMH dalam mendukung ketahanan energi nasional. Desain penelitian ini menggunakan pendekatan kualitatif dengan Prosedur Analisis Data Manual dan penentuan strategi dengan analisis SWOT dengan pendekatan kuantitatif. Hasil penelitian menunjukkan akseptabilitas PLTMH cukup rendah karena belum adanya kesamaan pendekatan pada tahap perencanaan pendidikan. Alternatif strategi terbaik adalah strategi SO (SWOT) dengan bobot sebesar 4.37, strategi ini meliputi kerjasama dengan kementerian terkait pembentukan koperasi dan BUMDes, kolaborasi dengan LSM, ketersediaan komponen lokal dan kemudahan teknologi PLTMH.
\end{abstract}

Kata kunci: Keamanan Energi, akseptabilitas PLTMH, SWOT Analysis, Jawa Barat.

\begin{abstract}
The response to community acceptance with commitment and independence can be the key to the success of renewable energy infrastructure development. This study analyzed the acceptability of MHPP development in West Java, the management system and coaching strategy by IBEKA as an LSM, and the strategies formulated to improve the acceptability of MHPP. This study's design used a qualitative approach with Manual Data Analysis Procedures and strategy determination with SWOT analysis with quantitative approach. The result of this study showed that the MHPP acceptability was low due to the lack of a common approach at the educational plan stage during the initial development process. The best alternative strategy is the SO (SWOT) strategy with a weight of 4.37, this strategy includes collaboration with ministries related to the formation of cooperative unions and BUMDes, collaboration with NGO, the availability of local components and the ease of MHPP technology.
\end{abstract}

Keywords: Energy Security, MHPP Acceptability, SWOT Analysis, West Java. 
Thamrin, dkk

\section{INTRODUCTION}

The development of renewable energy is one of the vital factors in state security, which will help a conducive environment in realizing national development goals. Therefore, the development of renewable energy is significant because Indonesia has abundant potential for renewable energy, such as geothermal, water, biomass, wind, solar, and urban waste. Two renewable energy sources having the highest potential are geothermal and water. The share of Large-scale Hydroelectric Power Plant (HPA) and Small-scale Hydroelectric Power Plants (MHPP) in total electricity output is higher than Geothermal Power Plants (GPP) because geothermal capacity lies in remote areas (Erinofiardi, et al., 2017). Referring to the third point of Nawacita, the Government intends to develop Indonesia from the periphery by strengthening regions and villages within the Republic of Indonesia. In August 2017, The Minister of Energy and Mineral Resources stated that more than 50 percent of the ministry budget of Rp 6.5 trillion was allocated for capital expenditure aimed at direct public welfare. Based on the Supreme Audit Agency (BPK) report, 142 projects stalled from a total of 708 construction projects of the renewable energy power plant during the period 2011-2017. As the plans have not been handed to the Government, Indonesia suffers a loss of Rp 1.17 Trillion (estimated) with an electricity capacity of $27.9 \mathrm{MW}$. Besides, the Directorate General of Renewable Energy and Energy Conservation (Dirjen EBTKE) sustained an injury of around Rp. 305 billion due to the renewable energy infrastructure, which was heavily damaged and Rp 133 billion in damaged condition. The damaged infrastructure is the total number of various types of renewable energy power plants, namely MHPP, Solar Power Plants PLTS, Wind Power Plants (PLTB), and Hybrid Power Plants (PLT Hibrida). In terms of budget, the largest budget allocation ( $90 \%$ ) of the Dirjen EBTKE is only related to the construction of power plants by the Directorate of Infrastructure. However, on a national contribution, this cannot be measured as an achievement of the energy mix. The amount of funds spent is not proportional to the results generated. For example, the realization of MHPP development is only $0.173 \mathrm{GW}$ out of 19.3 GW or around $1.19 \%$ of the total potential. This figure is still higher than the achievement of the overall renewable energy contribution in the National Energy Mix of $0.54 \%$ per year from the initial target of ignition each year of $0.9 \%$. From the results of inspections BPK identified various factors causing the renewable energy project to be stalled, as follows:damaged devices before being handed over; a protracted grant process at the Ministry of Finance; a change of Regional Head; difficulty in obtaining land acquisition licenses; lack of monitoring and evaluation by the Government (Najmurrokhman, et al., 2017).

MHPP construction project had to be canceled due to damage by several residents during the voluntary work of road widening because the construction was considered a conspiracy attempt to overthrow the village head. Another case occurred in the MHPP construction project in Watamakebo, Bibida District, Paniai Regency, Papua. The project was halted at the end of 2014 because of damage to turbines and had a large state budget. According to locals, initially, the turbine suffered a simple injury. Still, it worsened due to the lack of education to residents about the operation and maintenance of the community. Besides, there were no specialized technicians stationed in the area, so this project was abandoned. One of the fundamental causes of these various cases is the lack of acceptance of local communities, who, as beneficiaries, must understand the potential and impacts so that they can support by taking an active role in operations and monitoring (Heriawan, et al., 2018). One aspect of energy security, according to Benjamin K. Sovacool (Sovacool, 2009), is the stewardship that includes social values and environmental sustainability. Stewardship means ensuring the energy system that is built is socially acceptable. Energy needs to be considered as a vital factor because it is closely related to other sources of problems such as gender equality, social justice, and environmental damage. In line with the concept of energy security in Indonesia based on 
Kebijakan Energi Nasional (KEN), community acceptability is an essential factor in achieving energy security in an area. An excellent public acceptance response can be the key to the success of energy infrastructure development, especially renewable energy (Nazir, et al., 2014). Through an excellent initial response, local communities are expected to play an active role in the development of renewable energy infrastructure with commitment and independence in managing and maintaining the infrastructure that has been built by the Government to be sustainable (Burghardt, 2015).

There have not been many studies on the qualitative aspects of MHPP acceptability, especially in Indonesia. Mostly, previous studies focused on MHPP optimization and technical aspects (Nazir et al., 2014)(Tapia, et al., 2018). This research was focused on the case of MHPP failures, especially those caused by community acceptance constraints. Kasepuhan Ciptagelar Village is a traditional village that still upholds local wisdom. Located in the area of Kampung Sukamulya Sirnaresmi Village, Cisolok District, Sukabumi Regency, about 103 km from the central Government of Sukabumi Regency. With abundant natural potential, including water in it, Ciptagelar Village has several MHPP, that are actively operating. MHPP was first established by the Institut Bisnis - Ekonomi Kerakyatan (IBEKA) Foundation in collaboration with Japan International Cooperation Agency (JICA) in 1999, with a 65 kW capacity. The success of the MHPP named MHPP Cicemet initiated the formation of other MHPP in the same area. A few years later, an MHPP project was undertaken by the Government in this area. Unfortunately, the MHPP failed to operate and was eventually taken over by the IBEKA Foundation to perform again. This study aimed to 1)analyze the acceptability of MHPP development in Indonesia, especially West Java Province, to formulate strategies in supporting national energy security, 2)analyze the management system and coaching strategy undertaken by IBEKA as an NGO in the Kampung Kasepuhan Ciptagelar, Sukabumi area in achieving acceptability in the MHPP development project; 3)formulate strategies to improve the acceptability of MHPP in West Java Province in supporting national energy security.

\section{METHODS}

This research was quantitative and qualitative with belonged to a case study through understanding social phenomena that occur in society. Case study research seeks to find meaning, investigate processes, and gain an understanding and in-depth understanding of individuals, groups, or situations. Therefore, researchers chose to make direct observations at the location of case studies in a long time to get accurate primary data. The research was conducted in several places, namely MHPP Kampung Kasepuhan Ciptagelar, Cisolok District, Sukabumi Regency, West Java Province, Dirjen EBTKE, IBEKA Foundation. The subjects of this study included Dirjen EBTKE as the handler of the MHPP project, IBEKA Foundation, and the community as beneficiaries for the development of the MHPP project. The informants were selected to represent the population, namely the Directorate of Planning and Development of New Energy, Renewable Energy and Energy Conservation Infrastructure, Directorate of Various New and Renewable Energies; Ms. Tri Mumpuni as the co-founder of the IBEKA Foundation; The village apparatus and the Kasepuhan Adat Banten Kidul Ciptagelar community. In the data collection, the researcher started by conducting participant observation in an MHPP location for a specified period. In comparison, the non-participant inspection was carried out if the non-participant observation was not possible. Secondly, researchers conducted interviews with structured interview types. The discussion applied interview guidelines and data collection tools in voice recorders, cameras, and stationery. The researchers compared the MHPP development project that failed to operate in Kampung Kasepuhan Ciptagelar, Sukabumi, with the MHPP project working successfully now in the same 
area. The credibility of the findings shows how far the level of truth of the research results can be trusted. In this case, the researcher used a triangulation technique to check data by utilizing something outside of the data for checking or comparison purposes. The researchers described the results of research systematically following the sub-focus under study, namely the formation and inheritance of energy-saving cultures. Researchers categorize data following the formulation of the problem. Next, the researchers compiled an interim report containing events related to the study's purpose so that the conclusions regarding the reduction of data displays become more evident and easier to understand. At the data presentation stage, the provisional conclusions come from reducing the data collection classification and then presenting the data exposure. Next stage of drawing conclusions and verification to answer the formulation of problems. Conclusions are made based on reviewing interview results, observations, and reconsidering findings during the study. The researcher concludes by conducting a review of the field notes and testing the research data results' correctness (quantitative) to minimize data mismatches (Figure 1). In conformity, the researcher rechecked the data obtained through interviews, observations, and documentation studies to see whether the data collected was in accordance. The researchers also confirmed the data to the Dirjen IBTKE, the IBEKA Foundation, and the Head of Kasepuhan Ciptagelar Sukabumi Village.

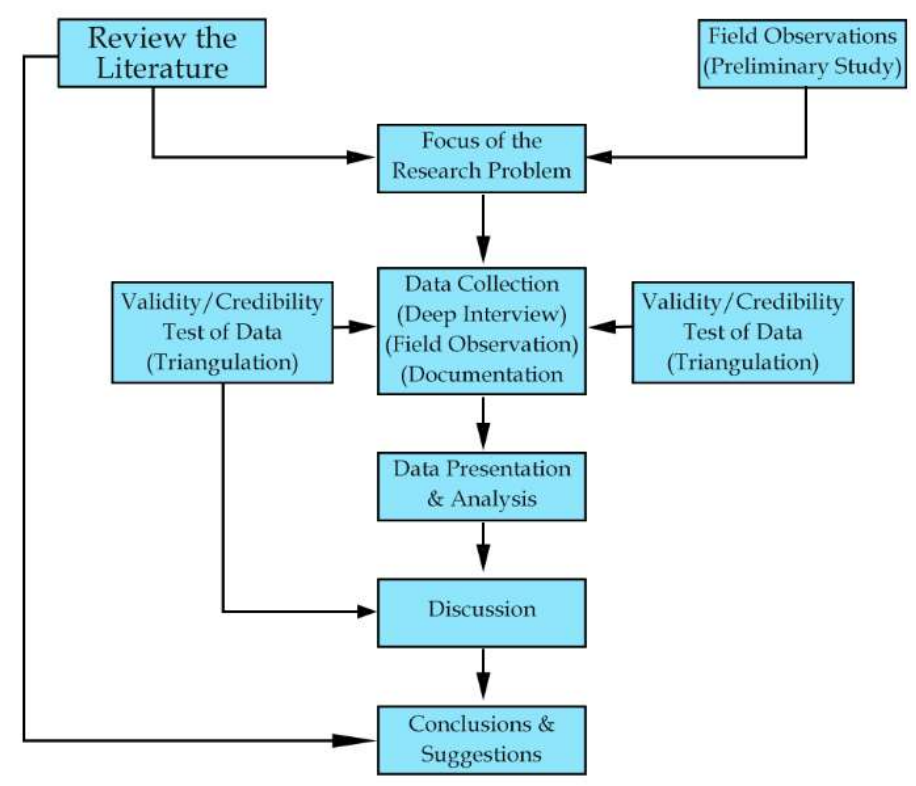

Figure 1. Research Flowchart

\section{RESULT AND DISCUSSION}

\subsection{MHPP Acceptability Analysis in Indonesia}

Acceptability is one of the most critical indicators of energy security. One sub-indicator of acceptability is community acceptance of energy infrastructure development (National Energy Council). If an energy infrastructure built does not get a good response, the community cannot participate actively. It is essential to emphasize the importance of a humane approach to energy supply services (Kengne Signe, et al., 2017). Jatin Nathwani, director of Affordable Energy for Humanity (AE4H), developed ecosystem mapping in the energy sector that included 
a grouping of key actors in the flow of funding, production, and distribution of energy to help actors in this sector understand their roles and tasks in the large-scale ecosystem of energy distribution systems. The diagram indicates that local preparation for energy consumers, including the population in an energy supply service environment, needs influencing people (Figure 2). Influencers can originate from social teams such as those undertaken by IBEKA or collaborate with NGOs as third parties.

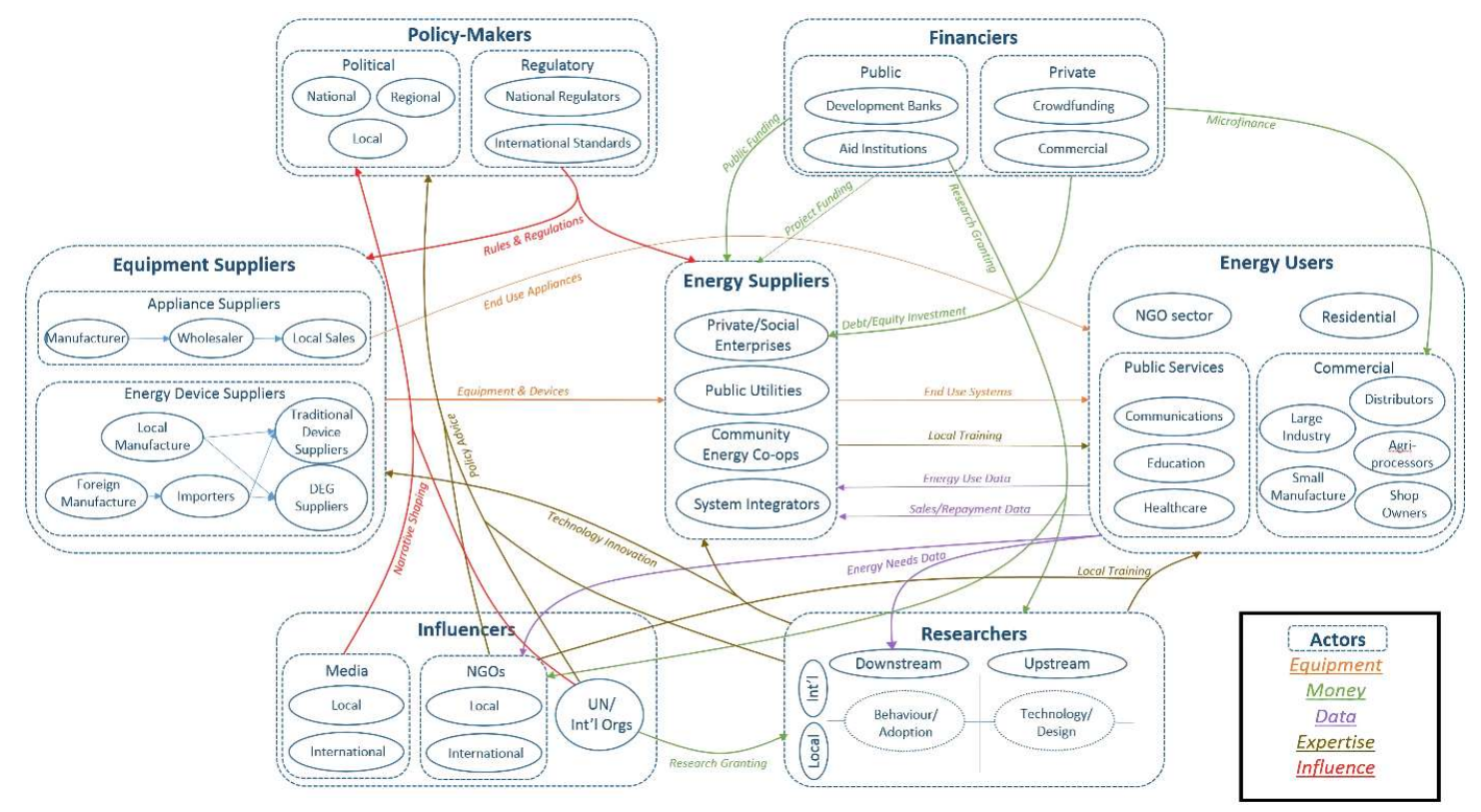

Figure 2. Energy Access Innovation Ecosystem

The Indonesian Ministry of Energy and Human Resources (KESDM) revitalize the MHPP because many renewable energy power plants could not be properly operated due to poor maintenance by the community as the beneficiary. They don't understand how to manage and repair installations when something goes wrong because they do not get enough knowledge. This condition worsened by the absence of monitoring and evaluation by the Government. The revitalization process needs budget and licensing because many power plants were damaged before being handed over to the Regional Government. During the transition period after Law No. 23 of 2014 was legalized, District / City ESDM Office was required to submit P3D during the transition period, which contained all the documents on existing assets. Very few did this well so that the Provincial Energy and Mineral Resources Office was quite overwhelmed. By regulation, district / city-level regional governments are still allowed to make budgets related to ESDM because they involve community services. The budget can be attached to the other related agencies' budgets, such as Public Works, to revitalize MHPP because the ESDM revoked is only its authority. Thus, there should be no reason for local governments to constrain by problems with the development or revitalization of renewable energy plants because there are no funds. In addition to the budget from the district/city level local government, the community can also use The Village Funds following the regulation of the Villages, Disadvantaged Regions, and Transmigration Minister No. 19 of 2017. Unfortunately, this was not applied because of the lack of dissemination.

\subsection{IBEKA Approach and Development Method}

IBEKA focused on improving the social economy of rural communities by developing local resources through local communities using appropriate technology. Therefore, acceptability is the primary key to achieve community independence. The introduction is the initial stage of 
community acceptability. This phase enters the common preparations carried out in the form of life-in, an activity designed so that one or several people can interact directly with people in social, economic, or cultural diversities (Foo, 2015). It is expected to be a useful multiculturalism learning tool so that it can form more positive stereotypes. In energy management, the introduction stage is part of the educational plan (Tripathi, et al., 2016). At each IBEKA project, a social team is deployed to carry out live-in. Based on experience, the more towards the east of Indonesia, the longer the live-in program is conducted. During the live-in, the social team mingled with the community, stayed one roof, and merged. One of the founders of IBEKA, Iskandar Budisaroso, explained that the social group during the live-in program followed the principle of "shut up and listen" where they had to leave the urban identity and be innocent by being more active as listeners. Live-in is needed to get a social mapping that includes the community's initial social conditions, the social order system, the mapping of stakeholders and local champions, and the identification of various problems on the ground that are and may occur. Also, a live-in program can be useful as a place to introduce people to IBEKA and donors.

Everett M. Rogers, through his book Diffusion of Innovation, explained that innovation could be communicated through a process of diffusion with specific channels to members of a social system within a specified period. In this research, the construction of MHPP is an innovation for the people of Kampung Kasepuhan Ciptagelar and IBEKA has a significant role in the diffusion process of these innovations. There are five main steps in the diffusion process of MHPP innovation, namely the emergence of knowledge, persuasion, decision-making process, implementation, and confirmation. 1) The emergence of knowledge includes the process when the community is directed to understand the existence of MHPP in the future. The next step is 2) persuasion, which is the formation of attitudes and behavior of the IBEKA team in the field to determine the final response and community decision making. In the third step, 3) the decision-making process, community participation has started to appear in various activities undertaken, both in the form of selecting and rejecting the development of MHPP as an innovation. In step 4) implementation, the Ciptagalar community, represented by Abah Ugi as the community leader, began to make decisions to participate in the construction of MHPP. Finally, 5) in the confirmation step, the community leaders seek to strengthen arguments that support the previous decision on acceptance of MHPP.The identification of social mapping is based on the theory of innovation diffusion illustrated in the figure 3.

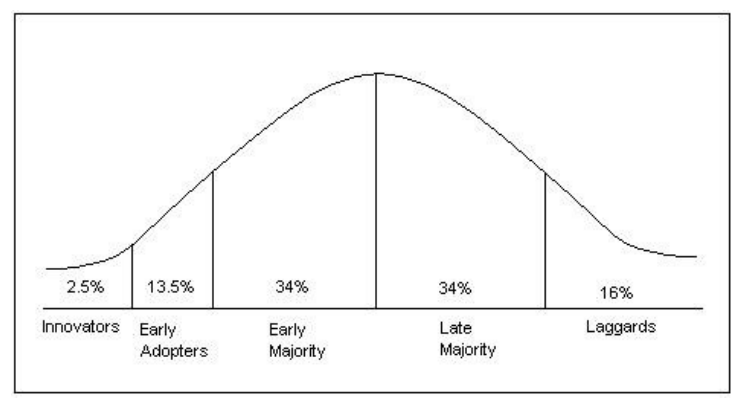

Figure 3. Adopter Categorization (innovation diffusion theory)

People who receive innovation can be referred as adopters in innovation diffusion theory, and can be categorized as follows (Figure 3): Innovators can be in the form of one or several individuals who first adopted the innovation. This group, which amounts to around $2.5 \%$ of the total population, is intelligent, has great mobilization, has a high economic capacity, and is brave enough to take risks. Abah Anom, as a traditional leader, is included in this group; 2) Early Adopters, a group of $13.5 \%$ who have the characteristics of exemplary community figures 
and have high access to this group's interests, are the pioneers in accepting the innovations received. In the construction of MHPP, the management and traditional elders were included in the early adopter's group; 3) The earlier majority has the highest percentage of $34 \%$. Although classified as an initial follower in innovation because it has a relatively high internal interaction, but this group includes many considerations. The majority of Kasepuhan Ciptagelar people are included in this group; 4) People in the group of Late Majority, having the same percentage as the early majority group, $34 \%$, tend to be more careful in making decisions to join in adopting innovation. In MHPP development, economic interests such as low basic electricity rates and electricity needs support the economic sector and further encourage the late majority group to accept MHPP innovation finally. 5) Laggards, who had a percentage of $16 \%$, belonged to the last group of people to adopt innovations that do not want to take the innovations completely. To prevent this, the IBEKA social team usually did not put the laggards in their concern. The presence of innovators and early adopters in the cultural groups can compete with rejections from the laggards.

Citizen participation in the development process is in the form of an agreement, and a community commitment is formed so that when the technical team has finished carrying out the feasibility study, the MHPP project can be executed. At this point, awareness to work hand in hand, remind each other, and criticize and give advice in the form of development, mutual cooperation, and management of MHPP appears. Community participation is not only in the initial stages of development but is a cycle, starting from planning, implementation, and closing with evaluation. In participatory community development, outsiders often interpret their role superficially as facilitators so that the outsider initiates the program's failure (Shaikh, et al., 2017). They will place the contributing factor on the local community, which is less participating, not failure on his part as a facilitator. Many outsiders target the provision of services or facilities to the community regardless of whether this is necessary. Besides, this happens without being accompanied by an initial process of community empowerment so that they meet their needs independently (Mishra, et al., 2015). The existing failures are considered to be the result of paternalistic fallacy, an incorrect approach because the Government applies a centralistic paradigm. Top-down decisions have resulted in unsustainable development initiatives, ineffective \& well-targeted development, or community reluctance and unpreparedness to continue the development (Nugroho, et al., 2015). The Government's decision-making paradigm should be replaced with a bottom-up, and the first stage is the first to be implemented. Also, the Government needs to involve the community. The community's active involvement in all stages of development, from planning to evaluation, is certainly different from the previous condition where the community only plays a passive role as a beneficiary. Direct community involvement was considered quite adequate at the micro-level, namely village, Rukun Warga (RW), to Rukun Tetangga (RT). The participatory approach methods such as Rapid Rural Appraisal (RRA), and Participatory Rural Appraisal (PRA) applied at the micro-level use a village because the macro-level approach involves the community more representative rather than active. A procedure at the micro level does not mean to be a small and trivial affair. Following the regional autonomy system, participatory approaches at the micro-level will be better able to explore resources and potential conflicts. Current renewable energy construction projects are frequently hampered by land procurement processes, social disputes, and customary micro-level disputes (Owusu \& AsumaduSarkodie, 2016). Effective group engagement must be balanced to become autonomous with intense and frequent assistance. Similar to a paternalistic fallacy, the populist fallacy has the opposite assumption that villagers feel they always know and understand their area better than outsiders. Therefore, a balance must be graded between a paternalistic and populist approach, involving external individuals supporting, assisting, and encouraging society (García-Gusano, et al., 2017). In the construction of the Cicemet MHPP, IBEKA was facilitated 
fully by Kasepuhan Cultural Community under the leadership of Abah Anom. After twenty years, the community was finally able to independently operate and maintain the MHPP. By attending various training, the people who are operators, in particular, can overcome multiple technical problems that arise without having to call in a technician or outside help. Because of this expertise, most young operators were often included in the other construction of MHPP. The program assessment can be measured from the report generation system (Steffen, 2018). The IBEKA team routinely carries out periodic evaluations and monitoring by checking directly in the field. Support usually lasts for 1-3 years, depending on the readiness of the community (Table 1 ).

IBEKA adopted the concept of Training for Rural Economic Empowerment (TREE) created by the International Labor Organization (ILO) in the economic development program. TREE aims to improve communities' welfare in rural areas based on community approaches and the development of local economic potential. There are four stages in the TREE method, which are organizational formation and planning, assessment of economic opportunities and training needed, program design, support, and delivery organizations, post-training support to develop microbusinesses and increase community income. IBEKA uses the TREE concept to improve Indonesian people's economic level, especially in the 3T areas (Behind, Leading, and Outermost). The high degree of community trust and participation formed after the construction of the MHPP is the initial capital of the IBEKA team in this method. On the economic development of Kasepuhan Ciptagelar after electrification resulting from the construction of the MHPP.

Table 1. Analysis of energy security indicators of PLTMH Kampung Kasepuhan Ciptagelar

\begin{tabular}{|c|c|c|}
\hline Aspects & Indicator & Descriptions \\
\hline \multirow{3}{*}{ 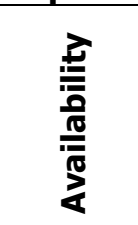 } & 1. Availability of river flow & The Cibarengkok and Cisonok rivers drain Ciptagelar village. \\
\hline & $\begin{array}{l}\text { 2. Discharge conditions and water } \\
\text { level }\end{array}$ & $\begin{array}{l}\text { The average river discharge is } 500 \mathrm{I} / \mathrm{s} \text { with the water source at a } \\
\text { sufficient height, considering the location on the mountain slope. }\end{array}$ \\
\hline & $\begin{array}{l}\text { 3. Availability of donors and } \\
\text { mentoring agencies }\end{array}$ & $\begin{array}{l}\text { The IBEKA Foundation first initiated the construction of the PLTMH as } \\
\text { a mentoring institution. It is still ongoing today with the assistance of } \\
\text { various donors such as JICA, PT. AHM, Adaro Energy and Bank Mandiri }\end{array}$ \\
\hline \multirow{3}{*}{ 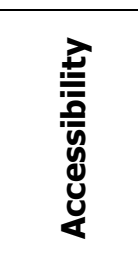 } & 4. Ease of technology & $\begin{array}{l}\text { MHPP technology tends to be simple and easy to operate, and its tools } \\
\text { have been widely produced domestically and make it easy for ToT to } \\
\text { the community. }\end{array}$ \\
\hline & 5. Inadequate road infrastructure & $\begin{array}{l}\text { Ciptagelar Village is quite isolated and is in the middle of the Mount } \\
\text { Halimun Salak National Park, with the road condition still in the form of } \\
\text { rocky soil. }\end{array}$ \\
\hline & 6. The distance to the city center & $\begin{array}{l}\text { Ciptagelar village is about } 45 \mathrm{~km} \text { from Pelabuhan Ratu as the city } \\
\text { center. }\end{array}$ \\
\hline \multirow{2}{*}{ 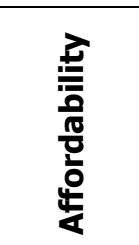 } & 7. Price comparison with PLN & $\begin{array}{l}\text { It was calculated based on the outcome of the deliberations that } \\
\text { Neighborhood contributions amounted to Rp. } 400 \text { / kWh, a lot less } \\
\text { costly than PLN TDL. Rp1,352 / kWh, } 900 \text { VA for the smaller family. }\end{array}$ \\
\hline & 8. Community economic conditions & $\begin{array}{l}\text { The majority of Ciptagelar Village people work as farmers with an } \\
\text { average income below the monthly minimum wage. }\end{array}$ \\
\hline \multirow{4}{*}{ 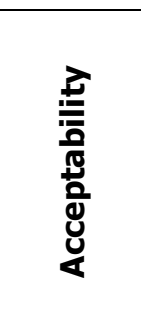 } & 9. Community response & $\begin{array}{l}\text { Community response is positive and quite enthusiastic because they } \\
\text { have never received electricity before, }\end{array}$ \\
\hline & $\begin{array}{l}\text { 10. Community participation in the } \\
\text { development }\end{array}$ & $\begin{array}{l}\text { The community's enthusiasm was marked by the high level of } \\
\text { community participation both from children, women, and men in } \\
\text { cooperation in building MHPP. }\end{array}$ \\
\hline & $\begin{array}{l}\text { 11. Community participation in } \\
\text { management }\end{array}$ & $\begin{array}{l}\text { The Ciptagelar social system in the form of Kasepuhan facilitates a } \\
\text { social approach because the community is under one command under } \\
\text { the leadership of Abah Ugi as the adat leader. }\end{array}$ \\
\hline & 12. Land use & $\begin{array}{l}\text { The land used for the construction of MHPP infrastructure is } \\
\text { communal, so it does not cause conflict. }\end{array}$ \\
\hline
\end{tabular}




\subsection{SWOT Analysis Results}

\subsubsection{Internal Factors Acceptability of PLTMH Development in West Java}

The culture of cooperation and deliberation is part of local wisdom (S4). This point obtained an average score of 8.08. Gotong-royong preserves through generations, especially for the people of West Java who live in rural areas. It symbolizes as collective energy and family spirit of community participation in development. At the same time, deliberation is a periodic activity usually carried out by the community before carrying out an action or making a decision (Mishra et al., 2015). People of West Java know deliberation as salawa, a conception of the nation's philosophy to reach consensus. Both types of cultural products become substantial capital owned by the community in building renewable energy infrastructure, especially MHPP. The level of active participation of local communities (S5). This community participation factor obtained an average value of 7.75. This factor is related to the previous element, which is the culture of cooperation and deliberation. West Java has a massive micro-hydro potential (S1). The amount of micro-hydro potential in West Java Province has an average value of 7.42. Even though it is not in the first rank, West Java Province has a massive enough potential, namely $647 \mathrm{MW}$, which is ranked 10 th. This value is $3.33 \%$ of the total potential of microhydro in Indonesia.

Table 2. Results of Respondents' Assessment of Internal

\begin{tabular}{|l|l|c|c|c|}
\hline & \multicolumn{1}{|c|}{ Internal Factors } & Value & Criteria & Code \\
\hline 1 & West Java has a massive micro-hydro potential & 7,42 & $\mathrm{~S}$ & $\mathrm{~S} 1$ \\
\hline 2 & $\begin{array}{l}\text { West Java 's Department of Energy and Mineral Resources vision compliance to } \\
\text { achieve energy security for society. }\end{array}$ & 7,42 & $\mathrm{~S}$ & $\mathrm{~S} 2$ \\
\hline $\mathbf{3}$ & $\begin{array}{l}\text { PLTMH technology is relatively easy to apply in the Transfer of Technology with the } \\
\text { community }\end{array}$ & 6,50 & $\mathrm{~S}$ & $\mathrm{~S} 3$ \\
\hline $\mathbf{4}$ & The culture of cooperation and deliberation as part of local wisdom & 8,08 & $\mathrm{~S}$ & $\mathrm{~S} 4$ \\
\hline $\mathbf{5}$ & The level of active participation of local communities & 7,75 & $\mathrm{~S}$ & $\mathrm{~S} 5$ \\
\hline 6 & The quality of local human resources in managing PLTMH & 6,50 & $\mathrm{~S}$ & $\mathrm{~S} 6$ \\
\hline 7 & $\begin{array}{l}\text { The length of time required for mapping and social approaches to pre-PLTMH } \\
\text { development }\end{array}$ & 6,08 & $\mathrm{~W}$ & W7 \\
\hline 8 & Lack of budget for social assistance pre and post the development of PLTMH & 5,67 & $\mathrm{~W}$ & W8 \\
\hline 9 & The complete lack of current data regarding PLTMH operating in West Java & 4,25 & $\mathrm{~W}$ & W9 \\
\hline 10 & PLTMH evaluation and monitoring system & 5,50 & $\mathrm{~W}$ & W10 \\
\hline 11 & Lack of a social team in the assessment and assistance process & 5,33 & W & W11 \\
\hline 12 & Availability of PLTMH components in the local market & 6,75 & $\mathrm{~S}$ & S12 \\
\hline 13 & Diversification of economic potential generated is as a PLTMH end-use product & 6,25 & W & W13 \\
\hline
\end{tabular}

West Java's Department of Energy and Mineral Resources vision compliance to achieve energy security for society (S2). This vision suitability factor gets an average value of 7.42. The main objective of the MHPP acceptability strategy is for the community to accept the development of MHPP with a high level of active participation so that the community can manage the renewable energy infrastructure independently and sustainably. To achieve this vision, the West Java government has a mission, including improving the quality of human resources managing energy, increasing the community's independence in meeting their energy needs, and increasing the role of energy sector actors in empowerment and community development activities. Availability of MHPP components in the local market (S12). The number of MHPP components available in the local market has become convenient for the community and the Government in building MHPP with a high domestic component level (Tingkat Komponen Dalam Negeri - TKDN). As operators and managers, the community will more readily buy replacement parts if there is damage during operation. MHPP components such as turbines and pipes can already be produced domestically. For West Java, workshops that sell these 
components are widely available in big cities like Bandung, so that this factor gets an average value of 6.75. MHPP technology is relatively easy to apply in the transfer of technology with the community (S3). Compared to other types of renewable energy plants such as solar and wind, MHPP technology is easy to operate and understandable. MHPP technology is also environmentally friendly and can operate continuously. This factor has an average value of 6.50. The quality of local human resources in managing MHPP (S6). This factor gets an average cost of 6.50. Although the majority of local human resources have a relatively low level of education, the work ethic of local human resources (especially the people of West Java) is high (Table 2). This has become a separate strength in the development and management of MHPP.

Diversification of economic potential generated is an MHPP end-use product (W13). This factor is considered a weakness for the Government of West Java in developing MHPP with a value of 6.25. Most MHPP has not functioned since the PLN electricity network reached the region. In contrast, MHPP can be used as a source of electricity from economic local community initiatives such as MSMEs and the SDA processing industry. Besides, it will provide the city with extra revenue and boost the economy. The length of time required for mapping and social approaches to pre-MHPP development (W7). The process of social approaching and social mapping requires a relatively long time. It varies in each region, which is influenced by several factors, including the community's socio-economic conditions, the potential for local conflict, the level of education, and local customs and culture. These factors cause the length of time that can not be accurately predicted. The Government and the developer do not have human resources and sufficient time to do this. This condition becomes a weakness in the community acceptance factor in the construction of MHPP with an average value of 6.08. Lack of budget for social assistance pre and post the development of MHPP (W8). Before and after the installation of the MHPP, social assistance was not a priority for the ESDM Department in West Java, so it was not included in the budget planning. This weakness factor gets an average value of 5.67 from respondents. MHPP evaluation and monitoring system (W10). Evaluation and monitoring are crucial stages of energy management. Unfortunately, the factor that gets an average value of 5.50 has not been done well. This factor is recognized by the West Java ESDM Service as a weakness that must be corrected. Lack of a social team in the assessment and assistance process (W11). In the stages of MHPP development, feasibility study or FS is a necessary process that must be carried out in addition to the DED preparation. Unfortunately, there are only technical teams in the process. Still, the existence of a social group is significant in conducting assessments in the form of social mapping and mentoring after the construction of the MHP. Therefore, this weakness factor gets an average value of 5.33. The complete lack of current data regarding MHPP operating in West Java (W9). After the ratification of Law Number 23 Year, 2014 concerning Regional Government, the authority and licensing of ESDM at the city/district level is removed and transferred to the provincial level. A shift should assist this transfer of power in inventory and data collection. Still, many ESDM offices at the city/district level do not have or submit complete data. This condition makes it difficult for the Provincial Energy and Mineral Resources Agency, especially West Java, to carry out an inventory of power plants, including MHPP. The incompleteness of the data represents a separate vulnerability for the West Java State, which results in a rating of 4.25.All internal variables have an average value of 6.42 . Factors with below-average values may be classified as weaknesses, whereas those with above-average values may be considered as strengths.

\subsubsection{External Factors Acceptability of PLTMH Development in West Java}

Collaboration with the Ministry of Cooperative unions and SMEs related to village cooperative unions' involvement as an MHPP management (O4). Cooperative unions are community-based economic organizations that are family and community-based. Existing village cooperative unions can also function as MHPP management, where the profits generated can later be 
utilized to produce other community businesses. Because of the size of the opportunity, this factor has an average value of 6.62. Cooperation with NGO on social mapping and group facilitation is following the establishment of MHPP (O1). NGO working in the renewable energy sector, especially MHPP, tend to have more experience in interacting with the community. This collaboration can be an opportunity for the Government of West Java to work together in terms of mapping and social assistance. This factor has an average value of 5.77. Collaboration with CSR companies/institutions in developing MHPP (O2). Therefore, investors and supporting institutions are needed, especially in terms of financing. The company's CSR program can be an equally profitable opportunity for the Government of West Java and the community. This opportunity factor gets an average value of 5.77. BOOT (Build Own, Operate, Transfer) scheme for renewable energy developers in MHPP(O9). With the BOOT scheme implemented by the central Government can develop high-quality MHPP, the developer's quality is guaranteed because the developer who will later hand over the power plant to PLN must pass the technical and developer capability test. For this reason, this factor received an average value of 5.46. Collaboration with the Kementerian Desa, Pembangunan Daerah Tertinggal and Transmigrasi (PDTT Ministry) and Badan Usaha Milik Negara (BUMN) Ministry on Badan Usaha Milik Desa (BUMDes) participation as MHPP management (O3). The establishment of BUMDes is expected to strengthen village economic institutions that can utilize the local economic potential. Like village cooperative unions, BUMDes is expected to function as an MHPP management body. This opportunity factor has an average value of 5.38.

Table 3. Results of Respondents' Assessment of External Factors

\begin{tabular}{|c|c|c|c|c|}
\hline & External Factors & Value & Criteria & Code \\
\hline 1 & $\begin{array}{l}\text { Cooperation with NGOs on social mapping and group facilitation is following the } \\
\text { establishment of PLTMH. }\end{array}$ & 5,77 & 0 & 01 \\
\hline 2 & Collaboration with CSR companies / institutions in developing PLTMH & 5,77 & O & $\mathrm{O} 2$ \\
\hline 3 & $\begin{array}{l}\text { Collaboration with PDTT Ministry and BUMN Ministry on BUMDes' participation as } \\
\text { PLTMH management }\end{array}$ & 5,38 & $\mathrm{O}$ & 03 \\
\hline 4 & $\begin{array}{l}\text { Collaboration with the Ministry of Cooperative unions and SMEs related to village } \\
\text { cooperative unions' involvement as a PLTMH management }\end{array}$ & 6,62 & 0 & 04 \\
\hline 5 & $\begin{array}{l}\text { Lack of verification of feasibility study data and detailed engineering design of pre- } \\
\text { PLTMH development }\end{array}$ & 5,08 & $\mathrm{~T}$ & T5 \\
\hline 6 & The entry of the PLN electricity network in remote areas & 4,54 & $\mathrm{~T}$ & T6 \\
\hline 7 & Interconnection of the PLTMH electricity network with PLN (on grid) & 4,31 & $\mathrm{~T}$ & T7 \\
\hline 8 & $\begin{array}{l}\text { The core grants and bureaucratic processes related to the development of an } \\
\text { extended PLTMH. }\end{array}$ & 5,15 & $T$ & T8 \\
\hline 9 & $\begin{array}{l}\text { BOOT (Build Own, Operate, Transfer) scheme for renewable energy developers, } \\
\text { especially PLTMH }\end{array}$ & 5,46 & $\mathrm{O}$ & 09 \\
\hline 10 & Licensing and regulatory systems are less supportive & 4,62 & $\mathrm{~T}$ & T10 \\
\hline 11 & Lack of training for local operators and means of developing MHP innovation & 5,15 & $\mathrm{~T}$ & T11 \\
\hline 12 & Lack of community education facilities about PLTMH & 4,77 & $\mathrm{~T}$ & T12 \\
\hline \multicolumn{2}{|r|}{ Average } & 5,22 & & \\
\hline
\end{tabular}

The core grants and bureaucratic processes are related to the development of an extended MHPP (T8). One of the causes of the slow progress of MHPP is the prolonged grant process at the Ministry of Finance (BPK Public Relations and International Cooperation Bureau). The governors' successions and the number of damaged plants before they were handed to the local Government also became an obstacle to the revitalization of the power plant. The bureaucracy process for the revival of power plants with large values can take up to a year, considering that it has to be approved by the President. This bureaucracy process poses a significant threat to the successful development of MHPP in West Java so that this factor has an average value of 5.15. Lack of training of local operators and facilities for developing MHPP innovations (T11). Generally, the operators appointed to operate MHPP are local people who still lack experience, so they are prone to confusion during operations. The lack of training and 
Thamrin, dkk

experience can be a threat to the success of MHPP in the area. This factor has a value of 5.15 . Lack of verification of feasibility study data and detailed engineering design of pre-MHPP development (T5). Feasibility study and Detail Engineering Design (DED) are carried out by developers who work together with local governments. The study findings were then submitted to the Central Government as information for MHPP development planning. Unfortunately, not all developers are doing well, so it is important to check the data. Limited human resources, time, and access to the area caused the minimum verification of data by the Central Government. This weight is a threat factor with a value of 5.08. Lack of community education facilities about MHPP (T12).

Table 4. Matrix of IFAS-EFAS Interactions

\begin{tabular}{|c|c|c|}
\hline EFAS & $\begin{array}{l}\text { Strength: } \\
\text { 1. Cultural cooperation and deliberation as part } \\
\text { of local wisdom } \\
\text { 2. The level of active participation of local } \\
\text { communities } \\
\text { 3. West Java has a massive micro-hydro } \\
\text { potential } \\
\text { 4. Conformity with the vision of the } \\
\text { Department of Energy and Mineral } \\
\text { Resources of West Java, namely the } \\
\text { realization of energy independence for the } \\
\text { welfare of society } \\
\text { 5. Availability of MHP components in the local } \\
\text { market } \\
\text { 6. MHP technology is relatively easy to apply in } \\
\text { the Transfer of Technology with the } \\
\text { community } \\
\text { 7. Quality of local human resources in } \\
\text { managing PLTMHWeight: } \mathbf{2 . 3 9}\end{array}$ & $\begin{array}{l}\text { Weakness: } \\
\text { 1. Diversification of economic potential } \\
\text { generated as a PLTMH end-use product } \\
\text { 2. The length of time required for mapping } \\
\text { and social approaches to pre-MHP } \\
\text { development } \\
\text { 3. Lack of budget for social assistance pre } \\
\text { and post-construction of PLTMH } \\
\text { 4. PLTMH evaluation and monitoring } \\
\text { system } \\
\text { 5. Lack of social teams in the assessment } \\
\text { and assistance process } \\
\text { 6. Complete lack of current data regarding } \\
\text { PLTMH operating in West Java } \\
\text { Weight: } \mathbf{0 . 9 7}\end{array}$ \\
\hline $\begin{array}{l}\text { Opportunity: } \\
\text { 1. Collaboration with the Ministry of } \\
\text { Cooperatives and SMEs related to village } \\
\text { cooperatives' involvement as a PLTMH } \\
\text { management. } \\
\text { 2. Collaboration with NGOs related to social } \\
\text { mapping and community assistance after the } \\
\text { construction of the PLTMH } \\
\text { 3. Collaboration with CSR companies / } \\
\text { institutions in developing PLTMH } \\
\text { 4. BOOT (Build Own, Operate, Transfer) } \\
\text { scheme for RENEWABLE ENERGY } \\
\text { developers, especially PLTMH } \\
\text { 5. Cooperation with the Ministry of PDTT and } \\
\text { the Ministry of BUMN, related to the } \\
\text { involvement of BUMDes. Weight: } \mathbf{1 , 9 8}\end{array}$ & $\begin{array}{l}\text { 1. Following the vision of the Department of } \\
\text { Energy and Mineral Resources of West Java } \\
\text { to realize energy independence for the } \\
\text { welfare of the community, collaboration } \\
\text { with ministries related to the formation of } \\
\text { cooperatives and BUMDes as a PLTMH } \\
\text { management agency needs to be done } \\
\text { immediately. } \\
\text { 2. Collaboration with NGOs needs to optimize } \\
\text { the culture of cooperation and consultation } \\
\text { that already exists to increase community } \\
\text { participation. } \\
\text { 3. The availability of local components and the } \\
\text { ease of PLTMH technology allow for more } \\
\text { significant investment opportunities from } \\
\text { corporate CSR. PLTMH training and } \\
\text { development can improve the quality of } \\
\text { local human resources. Weight: } \mathbf{4 . 3 7}\end{array}$ & $\begin{array}{l}\text { 1. The formation of cooperatives and } \\
\text { BUMDes can facilitate the diversification } \\
\text { of local economic potential as a PLTMH } \\
\text { end-use product. } \\
\text { 2. Collaboration with CSR companies and } \\
\text { other donor agencies can support } \\
\text { PLTMH financing, including social } \\
\text { assistance and post-development. } \\
\text { 3. The central government, in this case, } \\
\text { the MEMR, can improve the evaluation } \\
\text { and monitoring system through } \\
\text { collaboration with other Ministries, one } \\
\text { of which is by establishing an online } \\
\text { platform for reporting. } \\
\text { 4. Data collection on the condition of } \\
\text { PLTMH can be done in detail and } \\
\text { comprehensively by establishing UPT at } \\
\text { the city/regency level. Weight: } \mathbf{2 . 9 5}\end{array}$ \\
\hline $\begin{array}{l}\text { Threat: } \\
\text { 1. Central grants and bureaucratic processes } \\
\text { related to the development of protracted } \\
\text { MHPP. } \\
\text { 2. Lack of training of local operators and } \\
\text { facilities for developing PLTMH innovations } \\
\text { 3. Lack of verification of feasibility study data } \\
\text { and detailed engineering design of pre-MHP } \\
\text { development } \\
\text { 4. Lack of community education facilities about } \\
\text { PLTMH } \\
\text { 5. Licensing and regulatory systems are less } \\
\text { supportive } \\
\text { 6. The entry of the PLN electricity network in } \\
\text { remote areas } \\
\text { 7. PLTMH electricity network interconnection } \\
\text { with PLN(on-grid). } \\
\text { Weight: } \mathbf{1 , 1 1}\end{array}$ & $\begin{array}{l}\text { 1. Cutting regulations and permits that make it } \\
\text { challenging to develop the potential of } \\
\text { PLTMH in West Java Province. } \\
\text { 2. It is important to periodically verify FS and } \\
\text { DED data to build efficient and targeted } \\
\text { MHPPs. } \\
\text { 3. The establishment of a center of knowledge } \\
\text { as a means of education in each village. It } \\
\text { can increase the understanding and } \\
\text { competence of local communities. } \\
\text { Weight: } \mathbf{3 . 5}\end{array}$ & $\begin{array}{l}\text { 1. There is a need for additional education } \\
\text { about the opportunities on the grid } \\
\text { when the PLN network enters so that } \\
\text { the community does not feel burdened } \\
\text { and can sell electricity generated from } \\
\text { PLTMH to PLN to provide additional } \\
\text { benefits. } \\
\text { 2. Increasing the empowerment of local } \\
\text { communities as PLTMH operators and } \\
\text { administrators through workshops and } \\
\text { training so that the community has } \\
\text { specialized expertise can be useful for } \\
\text { finding additional income. } \\
\text { Weight: } \mathbf{2 . 0 8}\end{array}$ \\
\hline
\end{tabular}


The existence of MHPP indeed becomes something new for the community; therefore, society needs educational facilities that make it easier for the community to understand renewable energy generation technology. Lack of educational facilities can be a threat to the successful acceptance of MHPP in the community. Therefore the respondent gave an average value of 4.77. Licensing and regulatory systems are less supportive (T10). The licensing and bureaucratic systems that are complicated and tend to prolong developers' time allocation become a real threat to MHPP development's success. This system makes the average value of the factor to 4.62. The entry of the PLN electricity network in remote areas (T6). Initially, the formation of MHPP aims to increase electrification in rural areas, especially remote areas with no electricity at all or minimal power. The entry of the PLN electricity network is a threat to the community because it potentially causes MHPP not to be used again. This factor has an average value of 4.54. Interconnection of the MHPP electricity network with PLN (on-grid) (T7). In connection with the previous consideration, the operation of the PLN electricity network can be a threat to the community. The public prefers to use MHPP over network interconnection with PLN because the price is more affordable. This threat factor has an average value of 4.31 (Table 3 ).

It can be shown that the average value of all external variables is 5.22 , based on estimates. Factors with below-average values can be classified as risks, while elements above average can be classified as opportunities. After organizing internal factors into strengths and weaknesses and external factors into opportunities and threats, the IFAS - EFAS weighting is carried out as the next stage. Based on IFAS - EFAS weighting results, the strength factor that gets the highest average score is participation (gotong royong) and deliberation (musyawarah) as a part of local wisdom with an average value of 8.08. Both types of culture become substantial capital owned by the community in building renewable energy infrastructure, especially MHPP, to become the essential strength factor. The weakness factor that obtained the lowest average value is the incomplete current data regarding MHPP operating in West Java with a value of 4.25. After the ratification of Law Number 23, the Year 2014 concerning Regional Government, the authority and licensing of ESDM at the city/district level is removed and transferred to the provincial level. This power transition should be accompanied by a transformation in inventory and data collection, but several city / district-level ESDM offices do not have or send complete data. This case makes it difficult for the Provincial Energy and Mineral Resources Agency, especially West Java, to carry out an inventory of power plants, including MHPP. The incompleteness of the data is a separate weakness for the Government of West Java so that this factor becomes the weakest factor with the lowest value. The opportunity factor gets the highest average score in cooperation with the Ministry of Cooperative unions and SME related to involving village cooperative unions as an MHPP management body with a value of 6.62. Cooperative unions are community-based economic organizations that are family and community-based. Structurally the cooperative is under the auspices of the Ministry of Cooperatives unions and SME. In the context of MHPP development, existing village cooperatives can also function as MHPP management, where the profits generated can later be utilized to produce other community businesses. Because of this fact, this factor is the most significant opportunity factor. The threat factor that gets the lowest average value is the interconnection of the MHPP electricity network with PLN (on-grid) with a value of 4.31 . The entry of the PLN electricity network can be a threat to the community. The public prefers to use MHPP over network interconnection with PLN because the price is more affordable. The next step was conducting an interaction combination of strategies between internal and external factors to determine priorities and the interrelationships 
between the strategy based on their weighting. The formulation of the strategy is contained in the following IFAS - EFAS interaction matrices (Table 4).

\section{CONCLUSIONS}

The acceptability of renewable energy power plants, especially MHPP, is low due to the lack of a conventional approach at the educational plan stage during the initial development process. This lack of social strategy has caused many MHPP projects stalled and could not operate properly. Only $0.173 \mathrm{GW}$ out of $19.3 \mathrm{GW}$ of MHP potential can be realized. Therefore, a particular strategy is needed to increase people's acceptability to support the independence of energy infrastructure management to achieve national energy security. One way is to involve the social team in the initial introduction, assistance, and monitoring. In building MHPP, IBEKA has applied a community base where active community participation is the primary key to the success of sustainable development. A high sense of ownership is the result of community acceptability through the Training for Rural Economic Empowerment (TREE) strategy. IBEKA applied the concept of grassroots mobilization based on the theory of innovation diffusion as a common approach. Based on the SWOT analysis, the best alternative strategy is SO strategy in the form of: 1)following the Department of Energy and Mineral Resources of West Java's vision to realize energy independence for the welfare of the community, collaboration with ministries related to the formation of cooperative unions and BUMDes as an MHPP management agency needs to be done immediately; 2)collaboration with NGOs needs to optimize the cooperation and consultation culture that already exists to increase community participation; 3)the availability of local components and the ease of MHPP technology allow for more significant investment opportunities from corporate social responsibility. MHPP training and development can improve the quality of local human resources. The recommendations of this study are that the MHPP building process should be assisted with a knowledge center at the recipient object site. The community, as a beneficiary, and administrators can learn independently to solve problems from the experience of MHPP in other regions. One of the acculturation approaches is applying local wisdom in the construction of MHPP, which can be an effective solution to reduce the potential for conflicts and gaps between communities and the government or project owners. The involvement of nongovernment actors can be an active translator and liaison for the community and the Government to increase community acceptance. Empowering local champions as informal leaders can facilitate the community's approach in improving acceptance level.

\section{REFERENCES}

Burghardt, S. (2015). The Social Construction of Practice: Where Macro and Micro Meet on the Road Toward Personal and Community Transformation. In Macro Practice in Social Work for the 21st Century: Bridging the Macro-Micro Divide, (pp. 118-156). https://doi.org/10.4135/9781506374505.n6

Erinofiardi, E., Gokhale, P., Date, A., Akbarzadeh, A., Bismantolo, P., Suryono, A. F., Mainil, A.K., \& Nuramal, A. (2017). A Review on Micro Hydropower in Indonesia. Energy Procedia, 110, (pp. 316-321). https://doi.org/10.1016/j.egypro.2017.03.146

Foo, K. Y. (2015). A vision on the opportunities, policies and coping strategies for the energy security and green energy development in Malaysia. Renewable and Sustainable Energy 
Reviews, 51, 1477-1498. https://doi.org/10.1016/j.rser.2015.07.041

García-Gusano, D., Iribarren, D., \& Garraín, D. (2017). Prospective analysis of energy security: A practical life-cycle approach focused on renewable power generation and oriented towards policy-makers. Applied Energy, 19015), 891-901. https://doi.org/10.1016/j.apenergy.2017.01.011

Heriawan, D., Bambang, P.N., Sapei, A., \& Purwanto, Y.A. (2018). Sustainability Challenge of Micro Hydro Power Development in Indonesia. IOP Conference Series: Earth and Environmental Science, (pp. 1-8). https://doi.org/10.1088/1755-1315/147/1/012031

Mishra, M. K., Khare, N., \& Agrawal, A. B. (2015). Small hydro power in India: Current status and future perspectives. Renewable and Sustainable Energy Reviews, 51, 101-115. https://doi.org/10.1016/j.rser.2015.05.075

Najmurrokhman, A., Fakhri, Z., \& Reza, M. (2017). Pengembangan Pembangkit Listrik Tersebar Energi Baru Terbarukan dan Konversi Energi. Prosiding Seminar Nasional Teknik Elektro (FORTEI 2017), (pp. 39-44). https://doi.org/10.31219/osf.io/kr3wa

Nazir, R., Laksono, H. D., Waldi, E. P., Ekaputra, E., \& Coveria, P. (2014). Renewable energy sources optimization: A micro-grid model design. Energy Procedia, 52, 316-327. https://doi.org/10.1016/j.egypro.2014.07.083

Nugroho, Y., Adibroto, T. A., Tanaya, J., Amalia, D., \& Pawennei, I. (2015). Why Does Innovation Matter for Inclusive Development?: Some Evidence from Contemporary Indonesia. Social Transformations: Journal of the Global South, 3(2), 3-31. https://journals.ateneo.edu/ojs/index.php/ST/article/view/ST2015.03202.

Owusu, P. A., \& Asumadu-Sarkodie, S. (2016). A review of renewable energy sources, sustainability issues and climate change mitigation. Cogent Engineering, 3(1167990), 1-14. https://doi.org/10.1080/23311916.2016.1167990

Shaikh, P. H., Nor, N. B. M., Sahito, A. A., Nallagownden, P., Elamvazuthi, I., \& Shaikh, M. S. (2017). Building energy for sustainable development in Malaysia: A review. Renewable and Sustainable Energy Reviews, 75, 1392-1403. https://doi.org/10.1016/j.rser.2016.11.128

Signe, E. B. K., Hamandjoda, O., \& Nganhou, J. (2017). Methodology of Feasibility Studies of Micro-Hydro power plants in Cameroon: Case of the Micro-hydro of KEMKEN. Energy Procedia, 119, 17-28. https://doi.org/10.1016/j.egypro.2017.07.042

Sovacool, B. K. (2009). Reassessing Energy Security and the Trans-ASEAN Natural Gas Pipeline Network in Southeast Asia. Pacific Affairs, 82(3), 467-486. https://doi.org/10.5509/2009823467 
Steffen, B. (2018). The importance of project finance for renewable energy projects. Energy Economics, 69, 280-294. https://doi.org/10.1016/j.eneco.2017.11.006

Tapia, A., Millán, P., \& Gómez-Estern, F. (2018). Integer programming to optimize Micro-Hydro Power Plants for generic river profiles. Renewable Energy, 126, 905-914. https://doi.org/10.1016/j.renene.2018.04.003

Tripathi, L., Mishra, A. K., Dubey, A. K., Tripathi, C. B., \& Baredar, P. (2016). Renewable energy: An overview on its contribution in current energy scenario of India. Renewable and Sustainable Energy Reviews, 60, 226-233. https://doi.org/10.1016/j.rser.2016.01.047 